Review

\title{
Hydrogen Storage Technologies for Smart Grid Applications
}

\author{
Stavros Lazarou ${ }^{1, *}$ and Sofoklis Makridis ${ }^{2}$ \\ 1 Department of Electrical Engineering, Western Macedonia University of Applied Sciences, \\ GR50100 Kozani, Greece \\ 2 Department of Environmental and Natural Resources Management, University of Patras, \\ GR30100 Agrinio, Greece; smakridis@upatras.gr \\ * Correspondence: slazaroy@teiwm.gr
}

Academic Editor: Palmiro Poltronieri

Received: 28 March 2017; Accepted: 31 May 2017; Published: 8 June 2017

\begin{abstract}
The electricity sector is among the main contributors to carbon emissions. This sector has the potential to reduce its carbon emissions through producing electric energy from zero-emitting facilities and optimizing consumption to better accommodate low-carbon emissions. The use of hydrogen combined with smart grids, as analyzed in this manuscript, can substantially contribute to climate change mitigation.
\end{abstract}

Keywords: smart grid; hydrogen; liquid hydrogen; storage; power-to-gas; superconductivity

\section{Introduction}

"A smart grid is an electricity network that can integrate, in a cost-efficient manner, the behavior and actions of all users connected to it-generators, consumers and those that do both-in order to ensure an economically efficient, sustainable power system with low losses and high levels of quality and security of supply and safety." European Commission Task Force for Smart Grids.

After the Paris Agreement [1,2], new challenges and opportunities have emerged for the hydrogen economy. Fulfilling its objectives is a technically demanding exercise that requires the implementation and the advancement of all of the available technologies that can reduce carbon emissions. According to the United States Environmental Protection Agency, the electricity sector is among the main contributors to carbon emissions [3]. This sector has the potential to reduce its carbon emissions through producing electrical energy from zero-emitting facilities and through optimizing consumption to better accommodate low-carbon emissions. An important barrier in accommodating these requirements is that modern society depends on fossil fuels. Hydrogen could potentially be the means of overcoming this challenge. When combined with smart grids, as analyzed in this manuscript, it could substantially contribute towards the implementation of the Paris agreement.

Having mentioned the above, several technologies, such as smart grids, facilitate the transition towards a zero-carbon emissions society because they assist in the production from zero-emission sources. This idea is served by a substantial number of researchers who produce knowledge on the subject [4]. Their work focuses increasingly to this specific discipline, probably incentivized by the carbon emissions mitigation policies. However, it is important to define "smart grid" as it evolves in time on the way to meeting the new requirements [5]. The smart grid idea includes hardware, software, equipment, and operational procedures that facilitates the transition of the electricity system operation in a way that ensures the interconnected equipment exchanges its information is a manner that is friendly and safe. In this way, the intermittent renewables with zero carbon emissions can be better accommodated, and also energy efficiency measures can be easily taken to the consumers' side. Smart grids are treated on a multilayer basis since they affect policy for governments, technology 
for the industries, and organizational patterns for utilities. On a policy level, the ideas circulate around basic smart grid implementation concepts. On the international level [6], these include policies for reducing the burden of smart grid implementation for the utilities, the creation of incentives for dynamic pricing and smart metering, as well as the harmonization of regulatory regimes across jurisdictions. On the European level, the Energy Union and Third Electricity Package approaches the same issues regarding smart grid implementation. Especially for the European Grid, an extended inventory has been produced that shows increasing penetration of smart grids across the continent [7]. As far as the specifics of the technical requirements for smart grid implementation [8] are concerned, special attention is currently given to the technologies that contribute to the security, reliability, interoperability, environmental friendliness, user interaction improvement, and efficiency of the grid. To achieve these objectives, a selection of advancements is being conducted on storage and metering as far as hardware is concerned, and control and communications as far as software is concerned [9]. An important attribute of smart grids is their enhanced capability to receive increased penetration of renewables and distributed generation. However, they create specific technical challenges [10], such as the increase of short-circuit current, the bi-directional flow of energy, which requires advanced voltage control, differentiation for protection, and a change to the standard procedures for network planning. An important factor that facilitates the connection of renewables is the capability of smart grids to accommodate storage [11]. This attribute facilitates, except from the connection of intermittent renewables, the delay of the requirements for line expansion.

\section{Smart Grids and Energy Hydrogen Storage}

Hydrogen is able to demonstrate a substantial contribution to the electricity sector. Several researchers have demonstrated this objective. Luo et al. [12] provide an analysis of the technologies that can be applied to electricity energy storage. There is a selection of several storage options able to cover specific needs of the system, mostly in dealing with ancillary services. This is based on their energy capacity, as well as on their time capabilities to deliver it. Superconducting magnetic energy storage is able to immediately meet voltage transients, but their energy capacity is low. This makes them suitable for improving power quality to the end-user, and rectify voltage spikes and drops. Super-capacitors and flywheels are also able to deliver power instantaneously and maintain slightly higher energy capacity. This makes them better able to support the smart grid, as well as system ancillary services. Batteries, compared to the previous options, have the capability to provide better energy-rated capacity and longer operation time over nominal power. Batteries are sufficient for distribution grid operation and end-user systems. Fuel-cells, used as storage devices, are located in this segment. They are compact enough to be applied on the distribution and end-user level, and are able to deliver their nominal power for as much hydrogen as is available. This makes them suitable for relatively stable-power smart grid applications, with practically infinite energy storage capability near gas distribution networks. It has to be mentioned that bulk amounts of energy can also be stored at pumped-energy storage facilities, but this requires a large amount of space and installed capacity, suitable more for the transition electricity network than the smart grid. Analytically, limitations in terms of installation and operation requirements are available in Luo et al. [12]. The authors also provide a direct comparison of the available solutions, including hydrogen storage and the challenges they can meet specifically for the United Kingdom electricity system. It offers some complementarity, at least to the levels of end-users and smart grid support, distribution networks, and system ancillary services.

Kyriakopoulos and Arabatzis [13] offer a broad literature review of energy storage technologies. They claim that several types of storage, and specifically pumped hydro, synthetic natural gas and, to the interest of this project, hydrogen, are the most advanced in terms of their capabilities for direct implementation. This is of paramount importance because it provides the competency to research neutral carbon society supported by hydrogen energy storage.

Abate et al. [14] provide an analysis of the benefits of chemical energy conversion to the electricity grid, and they especially provide hydrogen storage technology benefits to off-grid applications. 
They explain that hydrogen has distinctive advantages, being able to offer trading options to off-grid systems. Wind, solar, and hydro are known as being abundant forms of renewable energy, but they demonstrate specific characteristics in terms of their intermittency and also in terms of their potential. Solar energy is available everywhere, but wind and hydro potential varies. Usually their potential is higher in regions scarcely inhabited, where traditional distribution networks are probably inadequately developed. This situation creates the challenge that produced energy cannot be consumed nor transferred through the traditional networks. Hydrogen and methane production, as a power to gas procedure, according to Abate et al. [14], is able to provide the technical capacity to create energy transfer networks. Hydrogen and methane produced from remote renewable energy through electrolysis can be stored and transferred for consumption where needed. Existing equipment, such as gas turbines, can be fueled using methane or new fuel cells can be installed. Hydrogen and methane can be a viable alternative to fossil fuels and provide solutions for the exploitation of remote renewable resources.

Schlogl [15] stipulates a more generic description of the situation, being able to specifically describe the potential contribution of the chemistry in dealing with the whole energy challenge. In this analysis, attention is given to the capability of chemistry to become the prominent solution in storing intermittent renewable energy in batteries or molecules, such as hydrogen and methane. Reiter and Lindorfer [16] introduce the potential of power-to-gas as a tool for energy storage, which is the prominent method to store molecules. On this subject, due to its importance, a specific chapter is provided below. Lopez-Gonzalez et al. [17] demonstrate the operational capability of a hybrid power system. The Instituto Nacional de Tecnica Aeroespacial (INTA) research and development experimental facility is comprised of an electrolyser and a metal hybrid container for hydrogen storage, able to be connected to fuel cells. The experiment has shown that hydrogen storage systems of this type demonstrate efficiency similar to batteries. Wendel et al. [18] analyzed the previous concept much further, proving its feasibility in practice of a reversible fuel cell instead of installing electrolysers and fuel cells and understanding its operational characteristics.

Special attention is given here to reversible fuel cells because of their potential to provide sufficient storage platforms. Bierschenk et al. [19] analysed the chemistry of a solid oxide fuel cell when it comes to round-trip efficiency (Figure 1). Here, it has to be mentioned that fuel cell thermodynamics limit the efficiency of reversible fuel cells below the efficiency of Li-ion batteries, but their capability to store energy without limits if they are connected to gas distribution systems is their main advantage.

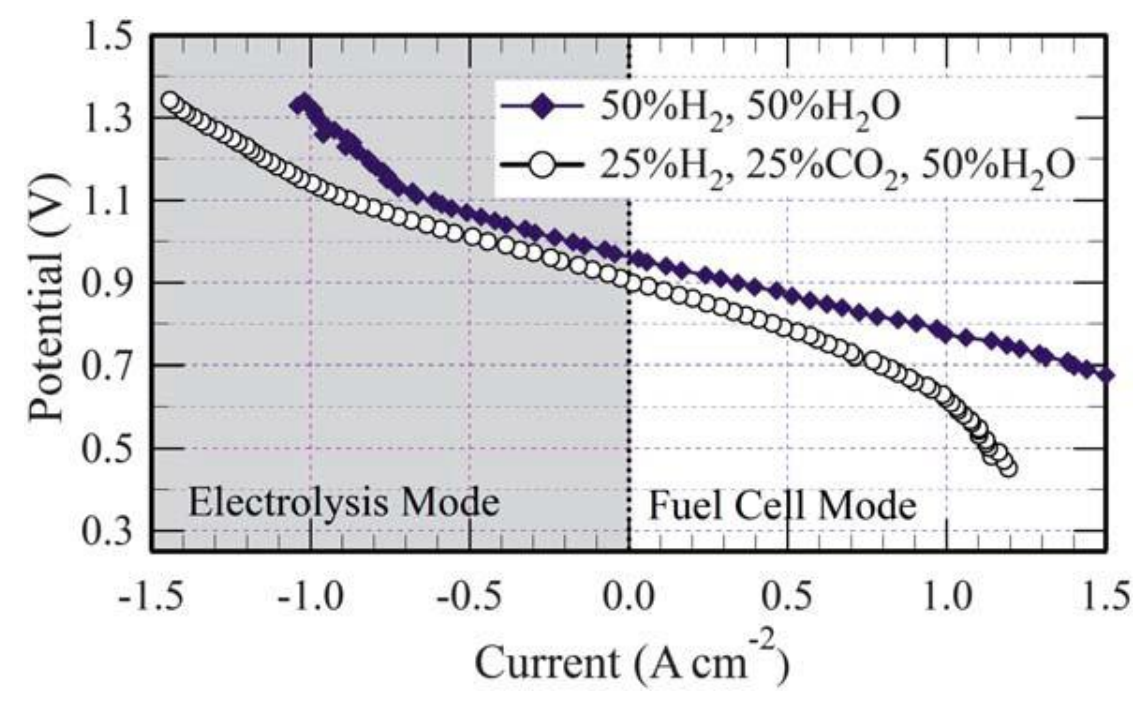

Figure 1. Voltage-to-current characteristics of a solid oxide fuel cell operating under different fuels (redrawn from [19]). 
A solution towards improving efficiency is to pressurise solid oxide fuel cells [20]. In this case, the current density increases and the activation and polarization losses decrease. More information on the specifics of fuel cells operation are provided below. The pressurised fuel cell offers a more viable solution for energy storage. However, its complexity increases and more space is required for installation.

An alternative solution for hydrogen storage is the rechargeable hydrogen battery [21]. In this case, the hydrogen produced from the reaction is stored chemically in a material through reduction. Several storage materials can be used, but they can be simple in terms of availability, such as iron [22]. The iron can be pure, with an oxide skeleton or iron with second oxide for intermediate oxide formation. The performance of the iron battery is also specifically investigated [23,24]. It appears that its performance, round-trip efficiency, and cycle stability require further improvement. In long-term charging and discharging experiments, these batteries [25] demonstrate average degradation, which leads to more than $40 \%$ charging material after 10,000 charging cycles. On average, as it is analysed, solid oxide fuel cell materials also degrade to a certain degree [26]. This degradation is mostly led by the anode of the system [27]. However, despite all of the above, it has to be mentioned that solid oxide fuel cell device installation proposals remain pertinent for solutions of a medium scale. This is the case since solid oxide fuel cells have high operating temperatures and their installed capacity is better fitted to a smart grid rather than residential use.

\section{Expected Complementarity of Hydrogen Technologies for Smart Grids with the Installation of Renewables}

Hydrogen technology is able to deliver unique solutions to complex problems for the implementation of a wider basis for the installation of renewables. As a matter of fact, hydrogen technology can be applied to remote installations where any other alternatives are not feasible. Offshore deep-sea renewables may be too remote to be directly connected to the electricity grid, or they move to different sites based on the requirements. Marine technology has shown the utility of these solutions. Floating wind turbine installations may use hydrogen to store the produced energy that can be collected and transferred to the mainland without the need of long-distance electricity grids.

In addition to the above, where the importance of hydrogen arises due to the absence of an electricity network, the technology can be applied in support of the ancillary services [28]. The electricity networks need to be able to deliver the energy required by the loads immediately and to cover the transmission and distribution losses. In the case this requirement is not fulfilled, the lack of available power stalls the system, creating blackouts. The transmission system operators, to be able to control the lack of power, apply a group of services called ancillaries. Energy producers receive a compensation to keep their facilities operating without producing energy, in order to be able to immediately withstand the loss of power due to a fault coming from another producer. Until recently, storage of electric energy had been too costly to be widely implemented, however, the technology of today is able to offer additional opportunities in this direction. Utilities are installing storage facilities at the distribution system level to meet peak demands without the need of keeping reserves.

Fuel cells are also able to deliver these services, but they introduce different behaviour. Batteries are capable of delivering peak loads for a shorter time, when fuel cells, especially when connected to the gas distribution network, consistently deliver their installed capacity for a long time.

Fuel cell installations produce methane and hydrogen to be fed to the gas network as a means of storing energy. The wide installation of renewable energy installations and their intermittency create new challenges to the electricity system. Renewables, most of the time, do not produce their installed capacity due to the absence of wind or solar irradiation at that point. This situation creates the need for the installation of excess installed capacity to meet the daily needs if they need to be met by renewables. The existing technology proposes curtailment. During this procedure, when the energy system is not able to absorb the produced energy, the producers from renewables are called to stall. This situation can lead to energy prices below zero. To avoid such extreme situations, a solution could be to install 
reversible fuel cell systems. In this case, the excess energy is not disposed to the atmosphere, but it is transferred to the gas network for immediate or future consumption.

Fuel cells in the electricity network are capable of delivering high efficiency with relatively small installations. This creates the opportunity to connect to the distribution level and deliver power nearer to the point of consumption. This creates lower transmission and distribution losses, contributes to the reduction of the need for network expansion, and maintains relatively high production efficiency. The benefits are environmental, societal, and on the energy security level: environmental, due to the reduction of losses; societal, due to the opposition of the society to the installation of new transmission and distribution lines; and energy-secure, since they produce energy of high efficiency.

\section{The Advantages of Installing Hydrogen Storage Facilities to Smart Grids}

Hydrogen storage facilities have been developed to the level to be considered a technology advanced enough to be implemented [29]. Nevertheless, there are still challenges. The main advantage of their implementation remains their much higher efficiency compared to thermal engines. For installations of the same small or medium capacity, where thermal reciprocal engines or turbines are used, the system efficiency is much lower compared to fuel cells. As a matter of fact, fuel cells demonstrate three different types of phenomena that create losses and reduce their efficiency. These are the ohmic, activation, and concentration losses, for which more information can be found [30]. A common characteristic to the majority of electric circuits and components are the ohmic losses. They appear due to electron flow and the resistance of the interconnections, cables, etc. Specifically, for fuel cells, the ohmic losses are low. Additionally, activation or reaction rate losses are connected to the chemical reaction. They are also relatively low, but the still exist. The concentration losses are connected to the reduction of the concentration caused by the depletion of reactants on the surface of the fuel cell electrodes. The concentration losses are also considered to be low. Having mentioned the above, it is possible that fuel cell installations of low or medium capacity are able to deliver much higher efficiency compared to any alternative. The situation can be different, though, for large power plants of hundreds of megawatts where turbines are able to achieve a level of high efficiency at reasonable costs. This is the reason being proposed in this manuscript: solutions to be applied to the smart grid rather than at the transmission system level. However, complementarity exists. For the automotive industry, which has the potential of switching from fossil fuels to hydrogen, fuel cell efficiency provides substantial operational improvements [31].

An additional feature of fuel cells is their reduced maintenance requirements due to the absence of moving parts compared to the main competing technology. Internal combustion engines are able to offer long operating life; however, they require frequent maintenance, and changing of parts and fluids. The maintenance reduces their capability to be installed in remote places and also the fluids need to be properly disposed of for environmental reasons. The low maintenance is also consistent with high system reliability. Fuel cells are able to withstand immediate load changes from stand still. Thermal engines, due to premature metal aging, need to be warmed before delivering their full capacity. This situation provides distinctive advantages for specific applications, such as covering the needs of the intermittent renewables. On the other hand, their capability to deliver their full load for a long time is an advantage compared to battery systems. Fuel cell installations can be used to produce electric energy and heat, but also the so-called cogeneration or combined heat and power (CHP) procedure. The produced heat can be used for residential or industrial purposes. It is, on average, of low cost, given that this energy otherwise would have been disposed of to the atmosphere. CHP is able to increase the total efficiency of the system; however, the production of heat is a by-product that is not always consumed. This may happen, for example, in countries where a moderate climate prevails, or there are low industrial energy requirements.

Hydrogen storage can be successfully combined with the existing gas distribution network. As it has been already mentioned, several researchers [16,32], describe different patterns such a solution. In this specific case, the authors propose the installation of a reversible fuel cell that is able to produce 
electricity from the gas network, and vice versa. This solution can effectively exploit the adjacent network. However, it cannot be applied to remote installations where the gas distribution network is not available. The main advantage compared to alternatives on the smart grid level is the unlimited potential for the amount of energy to be stored and withdrawn from the network. This technology, in terms of its capability to constantly withdraw or deliver power and the bulk amount of energy that can be stored, can be compared to pumped hydro storage. Nevertheless, pumped hydro storage is available where the geography allows it and requires intense installations as far as their installed capacity is concerned. Power-to-gas hydrogen storage can be materialized at the smart grid level, if the gas network is available, which is usually a matter of being able to offer the operational capabilities of large systems compactly and targeted near the consumption, decreasing network losses, and increasing its usability. There are several pathways for power-to-gas applications.

Specific power to gas solutions include solid oxide fuel cells. It is important, initially to understand the capability of this type of fuel cell to adequately deliver power-to-gas applications [33]. This application, as such, remains promising for storing bulk amounts of energy near gas pipeline networks, but its efficiency is confirmed to be, on average, lower than of the batteries if an electrolyser and one-way fuel cell is used. Theoretically, its efficiency can be substantially improved if an outside source of heat is available, but such a prerequisite is difficult to be found where smart grids are located. Solid oxide electrolysis cells can deliver this service, being able to achieve high efficiency if the exhaust heat from a methanator is recovered.

Figure 2 depicts the selection of pathways for hydrogen and methane storage. It is a cyclical procedure since the electric energy-producing material is eventually consumed to produce the same type of energy. However, this transformation provides distinctive advantages to storage and transportation. As a matter of fact, the electricity system without storage needs to consume all of the energy it produces or, in other words, to adequately satisfy the consumption. On the other hand, energy production from renewables remains intermittent, which is not always consistent with the consumption at any given time. Hydrogen storage can be a valuable solution to this challenge since it provides unlimited storage capability and the option of producing energy using the gas distribution system even if there is shortage of already-stored energy.

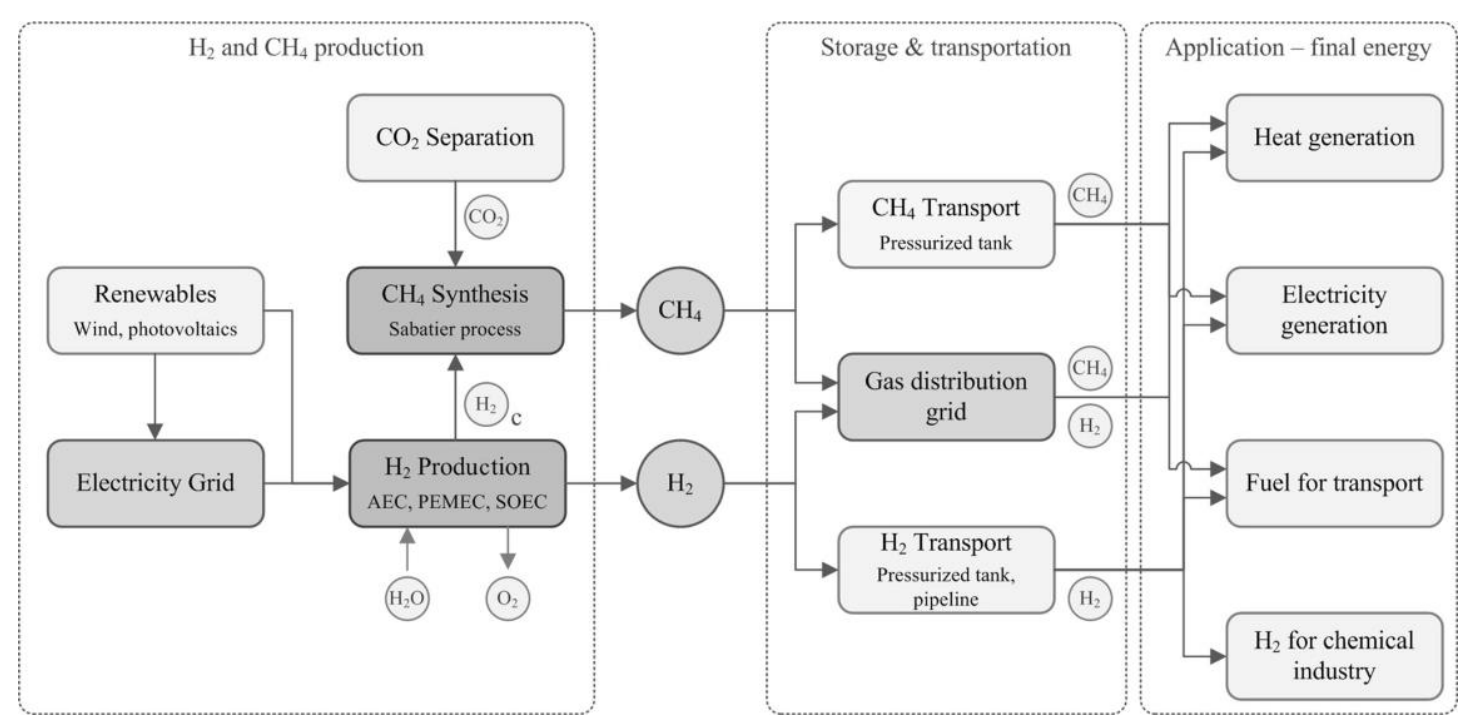

Figure 2. The power-to-gas system and its pathways (redrawn from [16]).

Closing this bibliographical analysis, hydrogen for electricity energy storage has been identified among different solutions as a viable solution for energy storage. Additionally, the research acknowledges further advancements on the implementation of hydrogen technology for storage 
that is able to provide additional features towards the implementation of a carbon-neutral society. However, these advances move forward on a different level for each country.

\section{The Smart Grid Advancements to the Electricity System}

As already mentioned at the introduction, smart grid technology has achieved the critical mass to gradually become an applied technology. Countries around the world, based on their individual requirements, resources, and needs, have advanced the subject in the way to better serve their interests [8,34]. According to the Smart Grid Federation Report [34], Canada, the United States, Japan, the United Kingdom, and South Korea have different key factors that affect their smart grid alignment. Canada needs to control an aging infrastructure, the United Kingdom has increased its gas imports, Japan is in the process of phasing out nuclear production, and South Korea is seeking to achieve higher energy efficiency. This report bases these findings on statistics produced by the International Energy Agency [35].

An issue of paramount importance, except from integrating zero carbon emission facilities, is the inadequate capability of the network to serve the future requirements. Based on this situation, smart grids for the case of Canada [34] were able to dynamically rate the capacity of a given line and widely control the system. Both of these attributes increase the capability of the existing lines to transfer energy, delaying new installations and optimizing the operation of the existing ones. Transmission lines' dynamic capacity rating is an exercise that involves dynamic stability analysis and a wide selection of data, such as of the generators, transformers, and lines, but also weather data and renewables' intermittent production.

Farid et al. [36] provide an extensive review of the situation, giving emphasis to the control of the future smart grid network. They explain that the study of the transmission network, due to smart grids, would be unified. That said, any technologies applied to the transmission network can also be scaled down to the distribution level. This is exactly the pattern applied by Mohtashami et al. [37] in providing a method for optimizing the expansion of the distribution network with distributed generators, a situation that appears in a smart grid.

The rest of the countries, such as South Korea, Ireland, Japan, the United States, and the European Union, give more attention to the implementation of the smart grid idea in a slightly different manner [8]. These countries created smart grid projects giving more emphasis to smart metering, electric vehicles, distributed generation, demand response, and to the development of advanced procedures for their control and communication across the elements. The above provide the capability to the network of being more resilient, flexible, and environmentally friendly.

Closing this section, it appears that the technologies seem to evolve based on the specific needs of each of the countries investing in smart grids. However, promising technologies, such as fuel cells at the distribution level, appear to be inadequately developed. Additionally, it remains clear that the plethora of different approaches across the countries also create issues of interoperability, harmonization, and eventually standardization, on a global level. International standardization bodies and professional organizations are dealing with the above.

\section{Smart Grid and Storage Standardization}

The variety of requirements, based on a plethora of needs across the globe, leads to uneven development of smart grid technologies. However, the electricity system, as a whole, requires interoperability. Additionally, it is already a greatly invested sector that is difficult to be replaced all at once, but only in sections across time when technology advances. The newer installations need to be able to operate effectively along with the existing ones, but also in a safe manner for the people who operate and use them. All of the above attributes need to be coordinated. This is achieved through standardizing procedures organized by international bodies, which are specialized in electricity systems, such as the International Electrotechnical Commission (IEC) [38], the Institute of Electrical and Electronic Engineers (IEEE) [39], on a global level, and the European Committee 
for Electrotechnical Standardization (CENELEC) [40], the European Committee for Standardization (CEN) [41], and the European Telecommunications Standards Institute (ETSI) [42] on the European level. All of the organizations above have allocated substantial resources to tackle the emerging issues of smart grids.

As far as CEN, CENELEC, and ETSI are concerned, they have accepted the mandate from the European Commission to develop and maintain the standardization procedure for smart grids at the European level. For this purpose, these standardization bodies have described the smart grid concept, as depicted in Figure 3 below. According to this, there are four main parts of the whole smart grid picture representing a different selection of stakeholders involved. These are the Operations, Users, Markets, and Energy Services components. The Operations include the traditional players of the energy system before smart grids. Specifically, they include the utilities, the system operators on the transmission and distribution level. The above serve the grid users, who are not only consumers, but also include the distributed generators, as well as storage and electric vehicles. The high-level operations of all stakeholders are described based on the energy services, in general, and the market.

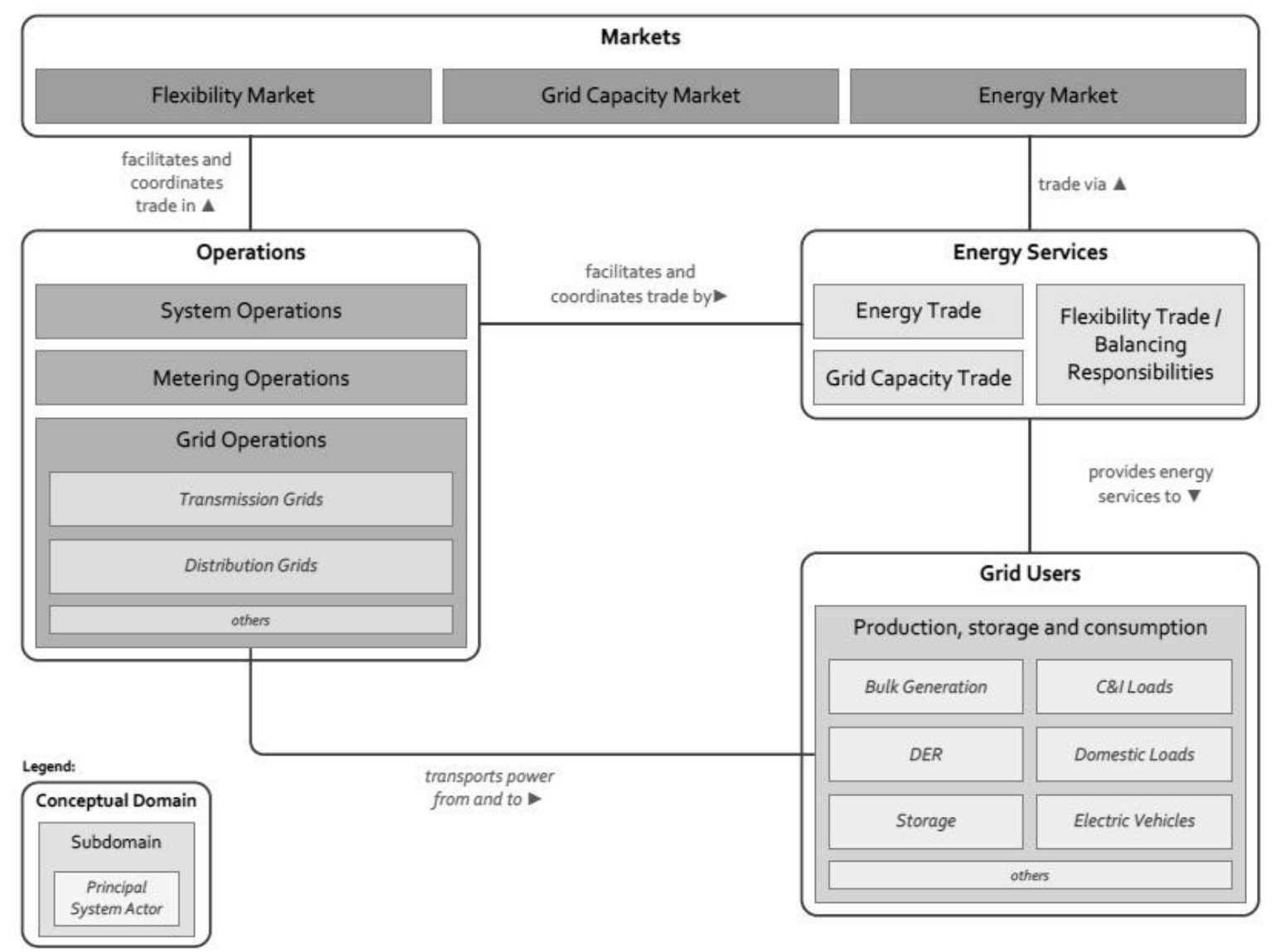

Figure 3. The European understanding of smart grid components (redrawn from [43]).

On the global level, the International Electrotechnical Committee has established a wide basis to create the standards that describe smart grid operation. It distinguishes the components of smart grids to the different levels of transmission, distribution, distributed generation, consumption, and communication. IEC categorizes the need of further developing smart grids to aging infrastructures, intermittent renewables, low cost of energy, issues of sustainability and societal changes. Sustainability is of paramount importance since it includes the emerging questions of carbon emissions reduction when the societal changes require the abolishment of the traditional energy monopolies to unbundled entities. 


\section{Future Hydrogen Storage Technologies for Smart Grids}

An emerging technology of hydrogen is superconductivity. Liquid hydrogen can be combined with superconductors to transfer energy in electric and chemical form. However, the experimental procedures to safeguard the capability of the system to adequately deliver remains to be improved. Mikheenko et al. [44] explain the usability of magneto-optical imaging in estimating the condition of superconducting materials. Further studies need to be conducted in order to provide valuable applications of this type. There are theoretical investigations into creating the infrastructure of a superconducting grid [45], such as building the conductor and its joints. The most likely material to be used is $\mathrm{MgB}_{2}$ [46], as it demonstrates appropriate structural and superconducting properties. Vysotsky et al. [47] performed the first experimental-scale approach using this material. They used Columbus Superconductor $\mathrm{MgB}_{2}$ wires. The results have shown adequate compatibility, but still experiments on the electrical operation of the system could be further applied. A larger installation of a 1 GW direct current line with 100 tons per day of hydrogen capacity has also been installed [48,49]. The results have shown a heat leak of $1 \mathrm{~W} / \mathrm{m}$ that requires a powerful cooling station. Additionally, bending properties of the wire material need further investigation. As a general discussion regarding the situation of superconducting cables with liquid hydrogen, they have the potential to provide a solution towards a zero-emission future [50]. However, many questions, such as aspects of cryogenics, safety, power, and materials, need to be further investigated [51].

\section{Conclusions}

Closing this manuscript, it appears that hydrogen technology presents extensive complementarity with smart grids. Fuel cells can be used to mitigate the consequences of intermittent renewable installations, to store energy produced remotely, and to facilitate the operation of the existing grid delaying its expansion. However, all of the above are not applied to the degree required due to technical challenges. These are the issues to be further investigated.

Acknowledgments: The authors express their appreciation to the reviewers, who provided their comments in terms of synthesis and contribution, improving this manuscript.

Author Contributions: Sofoklis Makridis provided and analyzed the data, and Stavros Lazarou wrote the paper.

Conflicts of Interest: The authors declare no conflict of interest.

\section{References}

1. United Nations Treaty Collection Repository. "Paris Agreement", 15 December 2015. Available online: https:/ / treaties.un.org/ (accessed on 10 November 2016).

2. United Nations Framework Convention on Climate Change. "Status of Ratification of the Convention", 9 May 1992. Available online: http://unfccc.int/essential_background/convention/status_of_ratification (accessed on 10 November 2016).

3. United States Environmental Protection Agency. “Overview of Greenhouse Gases”. Available online: https:/ / www3.epa.gov/climatechange/ghgemissions/gases/co2.html (accessed on 4 May 2017).

4. Wanga, L.; Zhao, L.; Mao, G.; Zuo, J.; Du, H. Way to accomplish low carbon development transformation: A bibliometric analysis during 1995-2014. Renew. Sustain. Energy Rev. 2017, 68, 57-69. [CrossRef]

5. Fang, X.; Misra, S.; Xue, G.; Yang, D. Smart Grid-The new and improved power grid: A survey. IEEE Commun. Surv. Tutor. 2012, 14, 944-980. [CrossRef]

6. Brown, M.A.; Zhou, S. Smart-grid policies: An international review. WIREs Energy Environ. 2013, 2, 121-139. [CrossRef]

7. Covrig, C.F.; Ardelean, M.; Vasiljevska, J.; Mengolini, A.; Fulli, G.; Amoiralis, E. Smart Grid Projects Outlook 2014; JRC Science and Policy Reports: Brussels, Belgium, 2015.

8. Tuballa, M.L.; Abundo, M.L. A review of the development of Smart Grid technologies. Renew. Sustain. Energy Rev. 2016, 59, 710-725. [CrossRef] 
9. Colak, I.; Sagiroglu, S.; Fulli, G.; Yesilbudak, M.; Covrig, C.-F. A survey on the critical issues in smart grid technologies. Renew. Sustain. Energy Rev. 2016, 54, 396-405. [CrossRef]

10. Pilo, F.; Celli, G.; Ghiani, E.; Soma, G.G. New electricity distribution network planning approaches for integrating renewables. WIREs Energy Environ. 2013, 2, 140-157. [CrossRef]

11. Zakeri, B.; Syri, S. Electrical energy storage systems: A comparative life cycle cost analysis. Renew. Sustain. Energy Rev. 2015, 42, 569-596. [CrossRef]

12. Luo, X.; Wang, J.; Dooner, M.; Clarke, J. Overview of current development in electrical energy storage technologies and the application potential in power system operation. Appl. Energy 2015, 137, 511-536. [CrossRef]

13. Kyriakopoulos, G.L.; Arabatzis, G. Electrical energy storage systems in electricity generation: Energy policies, innovative technologies, and regulatory regimes. Renew. Sustain. Energy Rev. 2016, 56, 1044-1067. [CrossRef]

14. Abate, S.; Centi, G.; Perathoner, S. Chemical energy conversion as enabling factor to move to a renewable energy economy. Green 2015, 5, 43-54. [CrossRef]

15. Schlogl, R. The role of chemistry in the energy challenge. Chem. Sus. Chem. 2010, 3, 209-222. [CrossRef] [PubMed]

16. Reiter, G.; Lindorfer, J. Global warming potential of hydrogen and methane production from renewable electricity via power-to-gas technology. Int. J. Life Cycle Assess. 2015, 20, 477-489. [CrossRef]

17. Gonzalez, E.L.; Llerena, F.I.; Perez, M.S.; Iglesias, F.R.; Macho, J.G. Energy evaluation of a solar hydrogen storage facility: Comparison with other electrical energy storage technologies. Int. J. Hydrog. Energy 2015, 40, 5518-5525. [CrossRef]

18. Wendel, C.; Kazempoor, P.; Braun, R. Novel electrical energy storage system based on reversible solid oxide cells: System design and operating conditions. J. Power Sources 2015, 276, 133-144. [CrossRef]

19. Bierschenk, D.M.; Wilson, J.R.; Barnett, S.A. High efficiency electrical energy storage using a methane-Oxygen solid oxide cell. Energy Environ. Sci. 2011, 4, 944-951. [CrossRef]

20. Kazempoor, P.; Wendel, C.H.; Braun, R.J. Pressurized regenerative solid oxide cells for electrical energy storage. ECS Trans. 2014, 58, 45-54. [CrossRef]

21. Berger, C.M.; Hospach, A.; Menzler, N.H.; Guillon, O.; Bram, M. Reversible oxygen-ion storage for solid oxide cells. ECS Trans. 2015, 68, 3241-3251. [CrossRef]

22. Menzler, N.H.; Hospach, A.; Niewolak, L.; Bram, M.; Tokariev, O.; Berger, C.; Orzessek, P.; Quadakkers, W.J.; Fang, Q.; Buchkremer, H.P. Power-to-storage-The use of an anode-supported solid oxide fuel cell as a high-temperature battery. ECS Trans. 2013, 57, 255-267. [CrossRef]

23. Erfurt, V.; Braun, W.; Spatschek, R.; Singheiser, L. Modelling of processes inside a rechargeable oxide battery. ECS Trans. 2016, 72, 15-34. [CrossRef]

24. Zhao, X.; Gong, Y.; Li, X.; Xu, N.; Huang, K. Performance of solid oxide iron-air battery operated at $550{ }^{\circ} \mathrm{C}$. J. Electrochem. Soc. 2013, 160, A1241-A1247. [CrossRef]

25. Leonide, A.; Drenckhahn, W.; Greiner, H.; Landes, H. Long term operation of rechargeable high temperature solid oxide batteries. J. Electrochem. Soc. 2014, 161, A1297-A1301. [CrossRef]

26. Chen, K.; Jiang, S.P. Review-Materials degradation of solid oxide electrolysis cells. J. Electrochem. Soc. 2016, 163, F3070-F3083. [CrossRef]

27. Zhao, X.; Xu, N.; Li, X.; Gong, Y.; Huang, K. Long-term stability study of a solid oxide "metal-air" battery. ECS Trans. 2013, 45, 113-121. [CrossRef]

28. Ewan, M.; Rocheleau, R.; Swider-Lyons, K.E.; Devlin, P.; Virji, M.; Randolf, G. Development of a hydrogen energy system as a grid frequency management tool. ECS Trans. 2016, 75, 403-419. [CrossRef]

29. Makridis, S. Chapter on hydrogen storage and compression. In Methane and Hydrogen for Energy Storage; Carriveau, R., Ting, D.S., Eds.; IET: London, UK, 2016.

30. Lazarou, S.; Pyrgioti, E.; Alexandridis, A.T. A simple electric circuit model for proton exchange membrane fuel cells. J. Power Sources 2009, 190, 380-386. [CrossRef]

31. Das, H.S.; Tan, C.W.; Yatim, A. Fuel cell hybrid electric vehicles: A review on power conditioning units and topologies. Renew. Sustain. Energy Rev. 2017, 76, 268-291. [CrossRef]

32. Müller, K.; Fabisch, F.; Arlt, W. Energy transport and storage using methanol as a carrier. Green 2014, 4, 19-25. [CrossRef]

33. Kato, T.; Nagata, S.; Honda, T.; Negishi, A.; Tanaka, Y.; Momma, A. Possibility of methane production from steam and carbon dioxide by using solid oxide electrolysis cells. ECS Trans. 2015, 68, 3513-3518. [CrossRef] 
34. Global Smart Grid Federation. Global Smart Grid Federation Report 2012; Global Smart Grid Federation: Toronto, ON, Canada, 2013.

35. International Energy Agency. Key World Energy Statistics 2016; International Energy Agency: Paris, French, 2016.

36. Farid, A.M.; Jiang, B.; Muzhikyan, A.; Youcef-Toumi, K. The need for holistic enterprise control assessment methods for the future electricity grid. Renew. Sustain. Energy Rev. 2016, 56, 669-685. [CrossRef]

37. Mohtashami, S.; Pudjianto, D.; Strbac, G. Strategic distribution network planning with Smart Grid technologies. IEEE Trans. Smart Grid 2016. [CrossRef]

38. International Electrotechnical Commission. Available online: http://www.iec.ch/ (accessed on 15 November 2016).

39. Institute of Electrical and Electronics Engineers. Available online: https://www.ieee.org/ (accessed on 15 November 2016).

40. European Committee for Electrotechnical Standardization. Available online: http://www.cenelec.eu/ (accessed on 15 November 2016).

41. European Committee for Standardization (CEN). Available online: http://www.cen.eu/ (accessed on 15 November 2016).

42. European Telecommunications Standards Institute (ETSI). Available online: http://www.etsi.org/ (accessed on 15 November 2017).

43. CEN-CENELEC-ETSI Smart Grid Coordination Group. SG-CG/M490/F_Overview of SG-CG Methodologies, Version 3; CEN-CENELEC-ETSI Smart Grid Coordination Group: Brussels, Belgium, 2014.

44. Mikheenko, P.; Yurchenko, V.; Cardwell, D.; Shi, Y.; Johansen, T. Magneto-optical imaging of superconductors for liquid hydrogen applications. J Supercond. Nov. Magn. 2013, 26, 1499-1502. [CrossRef]

45. Mikheenko, P.; Johansena, T.H. Smart superconducting grid. Energy Procedia 2014, 58, 73-78. [CrossRef]

46. Mikheenko, P. Superconductivity for hydrogen economy. J. Phys. Conf. Ser. 2011, 286. [CrossRef]

47. Vysotsky, V.S.; Nosov, A.A.; Fetisov, S.S.; Svalov, G.G.; Kostyuk, V.V.; Blagov, E.V.; Antyukhov, I.V.; Firsov, V.P.; Katorgin, B.I.; Rakhmanov, A.L. Hybrid energy transfer line with liquid hydrogen and superconducting $\mathrm{MgB}_{2}$ cable-First experimental proof of concept. IEEE Trans. Appl. Superconduc. 2013, 23, 5400906. [CrossRef]

48. Yamada, S.; Hishinuma, Y.; Uede, T.; Schippl, K.; Yanagi, N.; Mito, T.; Sato, M. Conceptual design of 1 GW class hybrid energy transfer line of hydrogen and electricity. J. Phys. Conf. Ser. 2010, 234. [CrossRef]

49. Yamada, S.; Hishinuma, Y.; Uede, T.; Schippl, K.; Motojima, O. Study on $1 \mathrm{GW}$ class hybrid energy transfer line of hydrogen and electricity. J. Phys. Conf. Ser. 2008, 97, 012167. [CrossRef]

50. Grant, B.P.M.; Starr, C.; Overbye, T.J. A power grid for the hydrogen economy. Sci. Am. 2008, 295, 76-83. [CrossRef]

51. Grant, P.M. The Supercable: Dual delivery of chemical and electric power. IEEE Trans. Appl. Superconduc. 2005, 15, 1810-1813. [CrossRef]

(C) 2017 by the authors. Licensee MDPI, Basel, Switzerland. This article is an open access article distributed under the terms and conditions of the Creative Commons Attribution (CC BY) license (http:// creativecommons.org/licenses/by/4.0/). 